Check for updates

Montreal

Cite this as: BMJ 2021;374:n1890 http://dx.doi.org/10.1136/bmj.n1890 Published: 27 July 2021

\title{
Covid-19: China stymies investigation into pandemic's origins
}

\section{Owen Dyer}

Prospects for a serious accounting of the origins of the covid-19 pandemic seemed more distant than ever this week, as the US and China traded barbs at a high level diplomatic meeting on 26 July, after China's apparent refusal to countenance any further investigation in Wuhan by the World Health Organization.

The theory that the novel coronavirus escaped from the Wuhan Institute of Virology has gained ground in recent months, ${ }^{1}$ not least because of suspicions generated by the extreme reticence of China's government.

But the question has also become entangled in US politics, as last week a Republican senator, Rand Paul of Kentucky, accused the US National Institutes of Health of funding "gain of function" research (that which alters an organism or disease to increase pathogenesis, transmissibility, or host range) into bat coronaviruses that might have made them transmissible to humans.

In a fractious televised exchange, Paul accused President Joe Biden's chief medical adviser, Anthony Fauci, of lying to Congress. In a May hearing Fauci told Congress that the NIH "has not ever and does not now fund gain-of-function research" at the Wuhan Institute.

The senator, who has clashed with Fauci repeatedly in hearings on the pandemic, asked him on 20 July, "Dr Fauci, knowing that it is a crime to lie to Congress, do you wish to retract your statement of 11 May where you claimed that the NIH never funded gain-of-function research in Wuhan?”

The NIH "has not ever and does not now fund gain-of-function research" at the Chinese laboratory, Fauci replied. "I have never lied before the Congress, and I do not retract that statement," he said, adding that the research had been "judged by qualified staff up and down the chain as not being gain-of-function."

"You are implying that what we did was responsible for the deaths of individuals," Fauci said. "I totally resent that. And if anybody's lying here, Senator, it is you."

It was "molecularly impossible" that the viruses created in the NIH sponsored research had evolved into the pandemic coronavirus, added Fauci.

Experts generally agree with that assessment, but some worry that it does not rule out the possibility of a wild bat virus being brought into circulation through the laboratory's activities, noting the extraordinary coincidence that a pandemic that was based on a bat coronavirus should begin in a city with a laboratory that specialises in bat coronaviruses.

\section{WHO doubts emerge}

An initial report from a WHO team sent to Wuhan struck many observers as premature in stating that a laboratory leak origin was "extremely unlikely."2 That conclusion was criticised by WHO's director general, Tedros Adhanom Ghebreyesus, who said on 15 July that there had been a "premature push" to rule out the leak theory.

"I was a lab technician myself, I'm an immunologist, and I have worked in the lab, and lab accidents happen,” Tedros said. “It's common.” He told reporters that WHO was "asking China to be transparent, open and to cooperate, especially on the information, [the] raw data that we asked for in the early days of the pandemic."

Records of meetings at the Geneva agency in the pandemic's first days, obtained by the Associated Press last year, suggest that WHO leaders' early praise of Chinese transparency was an effort to coax more information from the regime, while among themselves they expressed frustration at its secrecy.

Emergencies director Michael Ryan, who leads WHO's covid-19 response, privately compared China's behaviour unfavourably to the Democratic Republic of Congo's transparency over Ebola virus disease and noted that China had also delayed the release of vital information during the outbreak of severe acute respiratory syndrome (SARS) in 2003. ${ }^{3}$

China's government initially hoped that the pandemic would boost China's reputation as it provided the developing world with cheap vaccines and showcased its own tight infection control. But a recent poll in several countries showed that China's public image has taken a hit. ${ }^{4}$ Chinese vaccines, meanwhile, have been troubled by slow deliveries and limited efficacy.

A Chinese official last week dismissed WHO's plan for a second phase to its Wuhan investigation. "It is impossible for us to accept such an origin tracing plan," said Zeng Yixin, the vice minister of the National Health Commission, suggesting that WHO should instead investigate the United States. China's government has lent support to a conspiracy theory that blames the pandemic on the US military. ${ }^{5}$

"Their position is irresponsible and, frankly, dangerous," the White House said in response. "This is about saving lives in the future, and it's not a time to be stonewalling."

Biden has ordered US intelligence services to prepare an assessment on the leak theory. They are due to report back in late August.

Thacker PD. The covid-19 lab leak hypothesis: did the media fall victim to a misinformation campaign?BM/2021;374:n1656. doi: 10.1136/bmj.n1656 pmid: 34244293

2 Dyer O. Covid-19: WHO says laboratory escape theory is "extremely unlikely" after mission to China. BMJ 2021;372:n428. doi: 10.1136/bmj.n428 pmid: 33574118 
3 China delayed releasing coronavirus info, frustrating WHO. Associated Press. 2 Jun 2020. https://apnews.com/article/united-nations-health-ap-top-news-virus-outbreak-public-health3c061794970661042b18d5aeaaed9fae.

4 Silver L, Devlin K, Huang C. Large majorities say china does not respect the personal freedoms of its people. Pew Research Center. 30 Jun 2021. https://www.pewresearch.org/glob-

a//2021/06/30/large-majorities-say-china-does-not-respect-the-personal-freedoms-of-its-people.

5 Myers SL. China spins tale that the US army started the coronavirus epidemic. New York Times. 12 Mar 2020, updated 7 Jul 2021. https://www.nytimes.com/2020/03/13/world/asia/coronaviruschina-conspiracy-theory.html.

This article is made freely available for use in accordance with BMJ's website terms and conditions for the duration of the covid-19 pandemic or until otherwise determined by BMJ. You may use, download and print the article for any lawful, non-commercial purpose (including text and data mining) provided that all copyright notices and trade marks are retained. 